\title{
Comparative karyotype analysis and chromosome evolution in the genus Aplastodiscus (Cophomantini, Hylinae, Hylidae)
}

\author{
Simone Lilian Gruber ${ }^{*}$, Juliana Zina ${ }^{2}$, Hideki Narimatsu ${ }^{1}$, Célio Fernando Baptista Haddad ${ }^{3}$ and Sanae Kasahara ${ }^{1}$
}

\begin{abstract}
Background: The frogs of the Tribe Cophomantini present, in general, $2 n=24$ karyotype, but data on Aplastodiscus showed variation in diploid number from $2 n=24$ to $2 n=18$. Five species were karyotyped, one of them for the first time, using conventional and molecular cytogenetic techniques, with the aim to perform a comprehensive comparative analysis towards the understanding of chromosome evolution in light of the phylogeny.

Results: Aplastodiscus perviridis showed $2 n=24$, A. arildae and A. eugenioi, $2 n=22$, A. callipygius, $2 n=20$, and $A$. leucopygius, $2 n=18$. In the metaphase I cells of two species only bivalents occurred, whereas in $A$. arildae, $A$. callipygius, and A. leucopygius one tetravalent was also observed besides the bivalents. BrdU incorporation produced replication bands especially in the largest chromosomes, and a relatively good banding correspondence was noticed among some of them. Silver impregnation and FISH with an rDNA probe identified a single NOR pair: the 11 in A. perviridis and A. arildae; the 6 in A. eugenioi; and the 9 in A. callipygius and A. leucopygius. C-banding showed a predominantly centromeric distribution of the heterochromatin, and in one of the species distinct molecular composition was revealed by $\mathrm{CMA}_{3}$. The telomeric probe hybridised all chromosome ends and additionally disclosed the presence of telomere-like sequences in centromeric regions of three species.

Conclusions: Based on the hypothesis of $2 n=24$ ancestral karyotype for Aplastodiscus, and considering the karyotype differences and similarities, two evolutionary pathways through fusion events were suggested. One of them corresponded to the reduction of $2 n=24$ to 22 , and the other, the reduction of $2 n=24$ to 20 , and subsequently to 18 . Regarding the NOR, two conditions were recognised: plesiomorphy, represented by the homeologous small-sized NOR-bearing pairs, and derivation, represented by the NOR in a medium-sized pair. In spite of the apparent uniformity of C-banding patterns, heterogeneity in the molecular composition of some repetitive regions was revealed by $\mathrm{CMA}_{3}$ staining and by interstitial telomeric labelling. The meiotic tetravalent might be due to minute reciprocal translocations or to non-chiasmatic ectopic pairing between terminal repetitive sequences. The comparative cytogenetic analysis allowed to outline the chromosome evolution and contributed to enlighten the relationships within the genus Aplastodiscus.
\end{abstract}

Keywords: Amphibian, BrdU, FISH, Ag-NOR, C-band, $\mathrm{CMA}_{3}$, Phylogeny

\footnotetext{
* Correspondence: sisilgg@hotmail.com

1 UNESP, Universidade Estadual Paulista, Instituto de Biociências,

Departamento de Biologia, Av. 24A, 1515, 13506-900, Rio Claro, SP, Brazil

Full list of author information is available at the end of the article
} 


\section{Background}

The original description of Aplastodiscus Lutz, 1950, in the family Hylidae, was based on the species A. perviridis. However, many questions regarding the taxonomy of this genus remained, because the traits used for its characterisation were shared with representatives of the genus Hyla [1]. This fact led to the assignment of the name Hyla perviridis [2], and this species was included in the $H$. albomarginata group, along with $H$. albomarginata, $H$. albosignata, and $H$. albofrenata, due to, among other characters, the green colour typical of the species [3].

Based on morphological and bioacoustics data, as well as breeding behaviour of Hyla cochranae and H. perviridis [1], the genus Aplastodiscus was re-characterised, but the authors emphasised that further taxonomic studies were still necessary. Later, based on reproductive mode, it was suggested that the Hyla albosignata and $H$. albofrenata species complexes should be included in the genus Aplastodiscus [4]. Subsequently, comprehensive reviews of the taxonomy and phylogeny of the family Hylidae were performed [5,6], confirming the previous suggestion [4]. The 15 known species of Aplastodiscus are currently distributed into three groups: the $A$. albofrenatus group (A. albofrenatus, A. arildae, A. ehrhardti, A. eugenioi, $A$. weygoldti, and $A$. musicus), the A. albosignatus group (A. albosignatus, A. callipygius, A. cavicola, A. flumineus, A. ibirapitanga, A. leucopygius, and A. sibilatus), and the A. perviridis group (A. cochranae and $A$. perviridis) [7].

About half of the known species of Aplastodiscus have been karyotyped and the former analysis, based only on standard staining, showed $2 \mathrm{n}=24$ and $2 \mathrm{n}=22$ in $A$. albofrenatus, and $2 \mathrm{n}=20$ and $2 \mathrm{n}=18$ in A. albosignatus, collected in distinct Brazilian localities [8]. The author admitted that the different karyotypes might correspond, in fact, to distinct species.

Recently, four species of Aplastodiscus with $2 \mathrm{n}=22$, i.e., A. albofrenatus, A. arildae, A. ehrhardti, and A. eugenioi were karyotyped and some species-specific chromosome markers were found [9]. Analysing specimens of $A$. perviridis and $A$. cochranae with $2 \mathrm{n}=24, A$. albosignatus with $2 \mathrm{n}=20$, and $A$. leucopygius with $2 \mathrm{n}=18$, the same authors suggested that the karyotype differentiation of these species might have resulted from a reduction in the number of the small-sized chromosomes [10]. These data confirmed the karyotype variability in Aplastodiscus, an unusual finding in anurans, which are characterized, in general, by conserved chromosome constitution $[11,12]$.

In the present paper, a comprehensive comparative analysis was carried out for the first time based on five species of Aplastodiscus with distinct diploid numbers, one of them (A. callipygius) never karyotyped before. Besides Ag-NOR impregnation, C-banding, and FISH with probes of rDNA and of telomeric repeats, which had been previously used for some species $[9,10]$, the chromosomes of our sampled species were also analysed with fluorochrome staining and replication-banding after BrdU incorporation. The aim was to search for additional markers, towards a better understanding of chromosome evolution in light of the phylogeny $[5,6]$, contributing to make clear the relationships within the genus Aplastodiscus.

\section{Methods}

\section{Analysed species}

Cytogenetic analyses were performed on 28 individuals representing five species of Aplastodiscus (Table 1), collected in the states of São Paulo (SP) and Minas Gerais (MG). The animals were identified and deposited in the amphibian collection Célio Fernando Baptista Haddad (CFBH) housed in the Department of Zoology, UNESP, Rio Claro, SP, Brazil.

\section{Chromosome preparation and cytogenetic technique}

Direct cytological preparations were obtained from bone marrow, liver, and testes [13] and from intestinal epithelium [14]. In vivo treatment with 5-bromodeoxiuridine (BrdU) was carried out for some specimens [15]. The slides were standard stained with Giemsa, and submitted to Ag-NOR technique [16], C-banding [17], fluorochrome staining with AT-specific DAPI and GC-specific $\mathrm{CMA}_{3}$

Table 1 Species, number of individuals, sex, voucher number, and collecting localities in Brazil

\begin{tabular}{|c|c|c|c|c|}
\hline Species & Number & Sex & Voucher number (CFBH) & Collecting localities \\
\hline Aplastodiscus perviridis & 4 & males & $22394,22395,22401,22402$ & Camanducaia, MG \\
\hline \multirow[t]{2}{*}{ Aplastodiscus arildae } & 1 & male & 22387 & Serra do Japí, Jundiaí, SP \\
\hline & 4 & males & $28582,30409,30410,30411$ & Mogi das Cruzes, SP \\
\hline Aplastodiscus eugenioi & 2 & male, female & 22373, A505 & Ubatuba, SP \\
\hline Aplastodiscus callipygius & 7 & males & $7514,7515,7516,22396,22397,22403,22404$ & Camanducaia, MG \\
\hline \multirow[t]{3}{*}{ Aplastodiscus leucopygius } & 3 & males & 22389, A732, A733 & Serra do Japí, Jundiaí, SP \\
\hline & 1 & female & 22388 & \\
\hline & 6 & males & $28583,28584,30412,30413,30414,30415$ & Mogi das Cruzes, SP \\
\hline
\end{tabular}


[18], and replication band differentiation using Fluorochrome Plus Giemsa (FPG) or Acridine Orange [19,20]. The ribosomal probe HM123 [21] was hybridised using the fluorescence in situ hybridisation (FISH) technique [22] and a telomeric probe, following the manufacturer's manual (Dako Cytomation Denmark A/S Kit). The biarmed chromosomes were classified as metacentric, submetacentric, or subtelocentric by visual inspection, following the nomenclature of Green and Sessions [23,24].

\section{Results}

\section{Karyotype constitution and meiosis}

The specimens of $A$. perviridis showed $2 \mathrm{n}=24, \mathrm{FN}=48$ (Figure 1A), and a karyotype formed by five large pairs with slight variation in size from pairs 2 to 5 , one medium pair 6 , and six small pairs 7 to 12 , with subtle variation in size. Pair 1 was metacentric, pairs $2,3,4$, and 5 were submetacentric, pair 6 was subtelocentric, and the remaining pairs were classified as metacentric or submetacentric. Aplastodiscus arildae and A. eugenioi, with $2 \mathrm{n}=22, \mathrm{FN}=44$ (Figure $1 \mathrm{~B}, 1 \mathrm{C}$ ), had very similar karyotype constitution compared with $A$. perviridis, except that the small-sized group included five pairs 7 to 11 and that pair 2 was clearly metacentric. Aplastodiscus callipygius and $A$. leucopygius, with $2 \mathrm{n}=20, \mathrm{FN}=40$, and $2 \mathrm{n}=18, \mathrm{FN}=36$, respectively (Figure $1 \mathrm{D}, 1 \mathrm{E}$ ), exhibited large-sized pairs 1 to 7 , with slight variation from 2 to 7 , one medium pair 8 , and two small-sized pairs 9 and 10 in A. callipygius, and only one small-sized pair 9 in $A$. leucopygius. Pair 1 was metacentric, pairs 2 to 7 were submetacentric, pair 8 was subtelocentric, and the remaining pairs were metacentric or submetacentric in both species.
Secondary constriction was noticed in one or both homologues of chromosome pair 11 in A.perviridis and $A$. arildae, as well as in one or both homologues of chromosome pair 9 in A. callipygius and A. leucopygius. No sexrelated chromosome heteromorphism was observed in male (XY) or female (ZW) of A. eugenioi and A. leucopygius; neither in males (XY) of the remaining species.

In metaphase I cells of $A$. perviridis (Figure 2A) and $A$. eugenioi, 12 and 11 bivalents, respectively, were observed, while during metaphase II, 12 chromosomes were observed in the former species; for A. eugenioi this meiotic stage was not available. In A. arildae and A. callipygius, diplotene and metaphase I cells invariably showed one tetravalent, plus 9 and 8 bivalents, respectively (Figure 2B, 2C). Aplastodiscus callipygius exhibited 10 chromosomes in metaphase II cells, but this meiotic stage was not available for $A$. arildae. In metaphase I cells of $A$. leucopygius two of the nine bivalents appeared to be connected (Figure 2D), and during the metaphase II, 9 chromosomes were observed.

\section{Differential staining and FISH}

The technique of nucleolar organiser region by silver impregnation was performed in almost all individuals of the sampled species, excepting in two individuals of $A$. callipygius, showing a single pair of Ag-NOR: at the terminal region of the long arms of chromosome 11 in $A$. perviridis and $A$. arildae, at the terminal region of the long arms of chromosome 6 and 9 in A. eugenoi and A. callipygius, respectively, and at the terminal region of the short arms of chromosome 9 in A. leucopygius (Figure 1). One single Ag-NOR, as shown in Figure 1C for A. eugenioi, was observed eventually in metaphases of some of the individuals in all analysed species. The

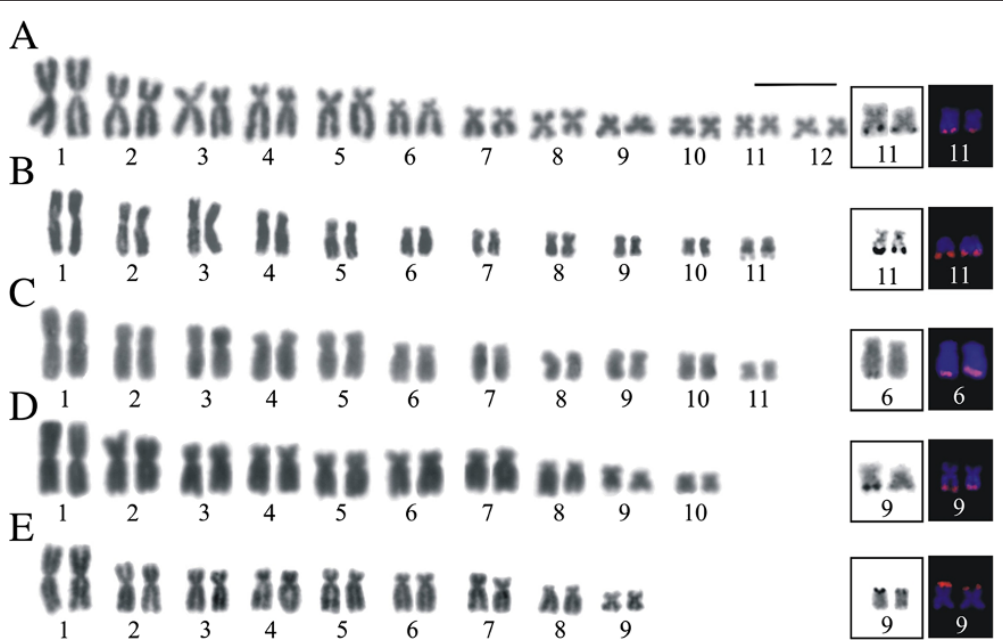

Figure 1 Giemsa-stained karyotypes of Aplastodiscus. A. A. perviridis, male, $2 n=24 ;$ B. A. arildae, male, $2 n=22 ;$ C. A. eugenioi, male, $2 n=22 ;$ D. A. callipygius, male, $2 n=20$. E. A. leucopygius, male, $2 n=18$. Insets show marker pairs, visualised by Ag-NOR and FISH with the rDNA probe. Bar $=10 \mu \mathrm{m}$. 


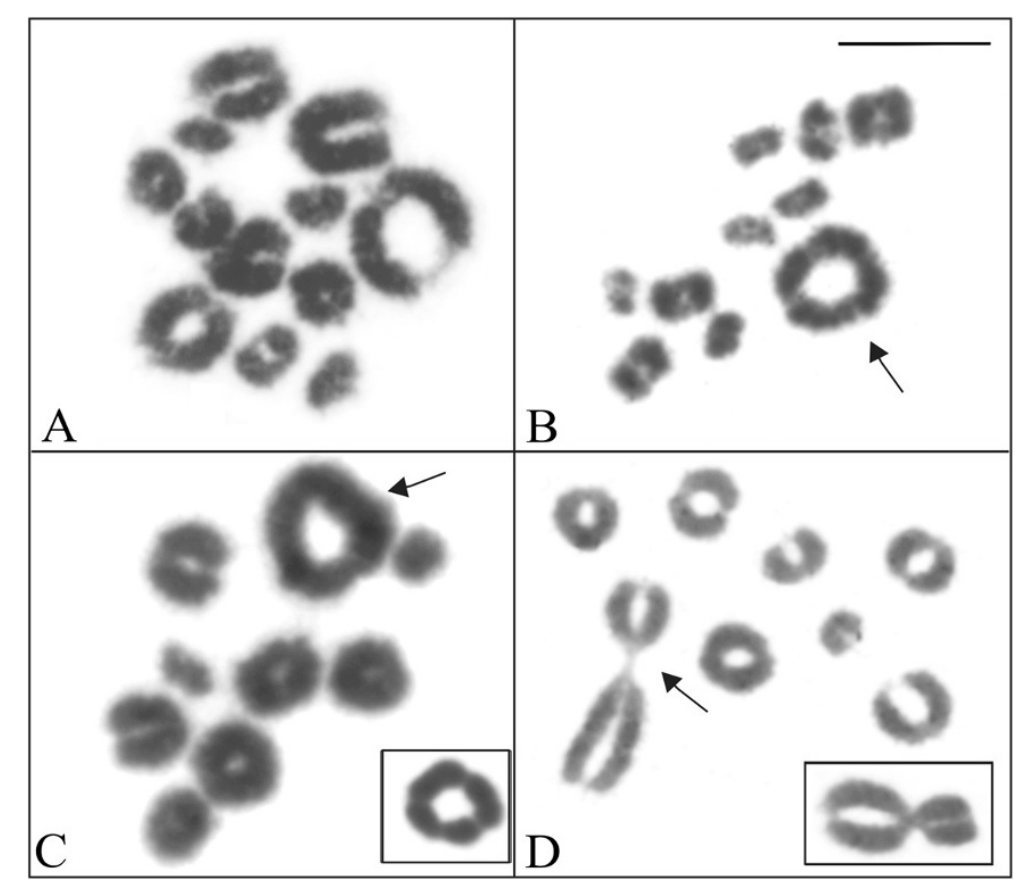

Figure 2 Giemsa-stained meiotic cells of Aplastodiscus. A. metaphase I of A. perviridis, with 12 bivalents; B. metaphase I of A. arildae, with nine bivalents and one quadrivalent (arrow); C. metaphase I of A. callipygius, with eight bivalents and one quadrivalent (arrow and inset); D. metaphase I of A. leucopygius, with nine bivalents (arrow and inset, connected bivalents). Bar $=10 \mu \mathrm{m}$.

sites of Ag-impregnation were coincident with the secondary constrictions in most cases. The FISH technique carried out in one single individual of each species confirmed that ribosomal sequences were in the sites previously identified by silver impregnation, always in the two homologues of the corresponding NOR-bearing pair (Figure 1).
The heterochromatin in all species had a predominantly centromeric distribution, with additional labelling at the NOR site (Figure 3), but in some metaphases this $\mathrm{C}$-band was very slight or not well visualised as in the Figure $3 \mathrm{C}$ for $A$. eugenioi. Fluorochrome staining was carried out in four species, with exception of $A$. eugenioi. In $A$. perviridis, bright fluorescence was observed with $\mathrm{CMA}_{3}$ in the NOR and in the centromere of all

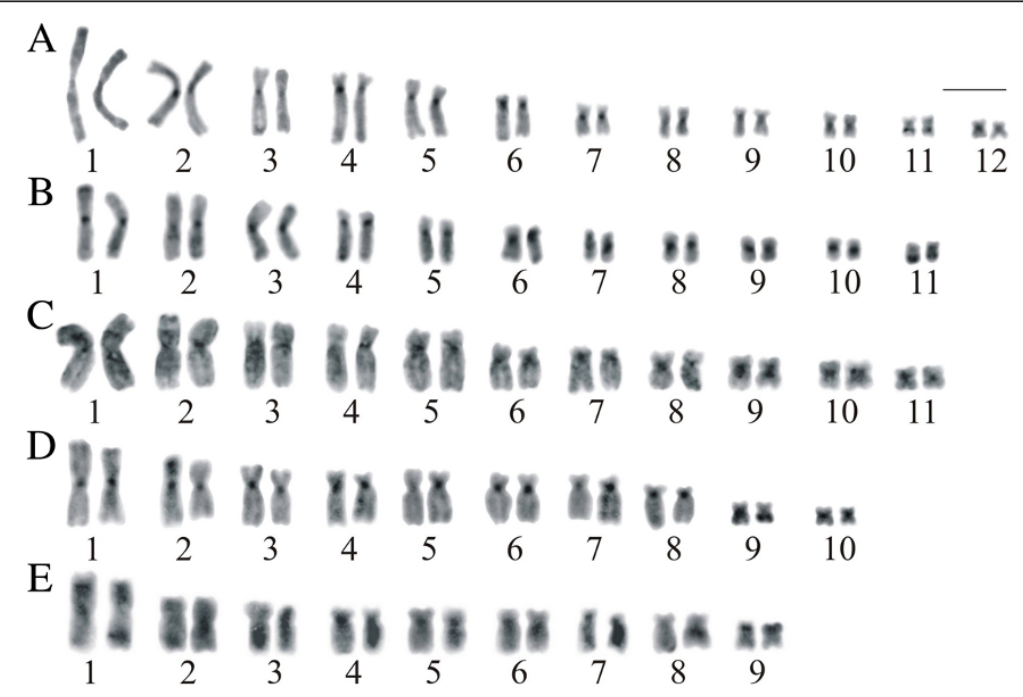

Figure 3 C-banded karyotypes of Aplastodiscus. A. A. perviridis; B. A. arildae; C. A. engenioi; D. A. callipygius; E. A. leucopygius. Bar $=10 \mu \mathrm{m}$. 


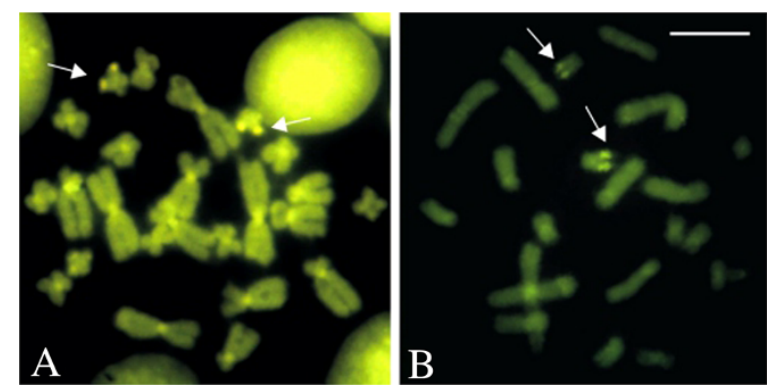

Figure $4 \mathrm{CMA}_{3}$-stained metaphases of Aplastodiscus. A. A. perviridis; B. A. arildae. Bright $\mathrm{CMA}_{3}$ fluorescence at the NOR site (arrow) and in $\mathrm{A}$, also in the centromeric region of the chromosomes. Bar $=10 \mu \mathrm{m}$.

chromosomes, but less brilliant in the small-sized chromosomes (Figure 4A). Fluorescence at the NOR site was also observed in A. arildae (Figure 4B), A. callipygius, and $A$. leucopygius (data not shown). When stained with DAPI, no particular brilliant region was observed in the chromosomes of any of the four species.

Telomeric probe hybridised all chromosome ends in A. perviridis and A. callipygius (Figure 5A, 5C), whereas in A. leucopygius additional labelling of interstitial telomeric sequence (ITS) was observed at the centromere region of chromosome 3 (Figure 5D). In $A$. arildae (Figure $5 \mathrm{~B}$ ) and $A$. eugenioi, hybridisation occurred in the telomeres and centromeres of all chromosomes,

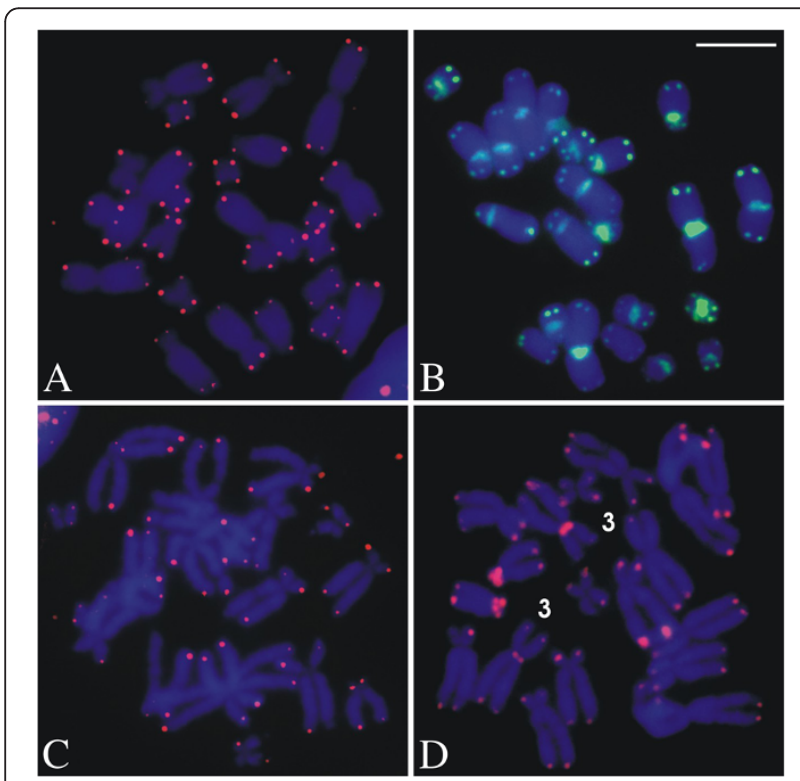

Figure 5 FISH using a telomeric probe in metaphases of Aplastodiscus. A. A. perviridis; B. A. arildae; C. A. callipygius; D. A. leucopygius. A hybridisation signal is seen in the centromeric region of chromosome 3 of $A$. leucopygius and in the chromosomes of $A$. arildae. $\mathrm{Bar}=10 \mu \mathrm{m}$. although the fluorescent labelling was subtle in the latter species.

Incorporation by BrdU carried out in A. perviridis, $A$. arildae, A. callipygius, and A. leucopygius produced replication bands especially in the largest chromosomes, whereas the smallest chromosomes showed poor differentiation (Figure 6). In spite of the distinct degrees of banding differentiation, tentative inter-specific comparisons were performed among the large and mediumsized chromosomes, showing relatively good banding correspondence among some chromosomes (e.g., the 1 and the 5 of the four species, the 2 and the 3 of $A$. perviridis, A. callipygius, and A. leucopygius, the 6 of A.perviridis and the 8 of $A$. leucopygius), and roughly the same banding feature for some others (the 4 of the four species).

\section{Discussion and Conclusions}

The present cytogenetic analysis confirmed the variability of $2 \mathrm{n}=24,2 \mathrm{n}=22,2 \mathrm{n}=20$, and $2 \mathrm{n}=18$ within the genus Aplastodiscus, contrary to that is commonly observed in the subfamily Hylinae, in general with invariable $2 \mathrm{n}=24$ karyotypes [25]. Distinct diploid numbers in Aplastodiscus were originally reported [8] and, more recently, the sample of karyotyped species was enlarged $[9,10]$. Taking into account our report on $A$. callipygius, analysed here for the first time, a total of nine representatives of the genus now have described karyotypes: A. cochranae and A. perviridis (A. perviridis group) with $2 \mathrm{n}=24 ; A$. albofrenatus, $A$. arildae, $A$. ehrhardti, and $A$. eugenioi ( $A$. albofrenatus group) with $2 \mathrm{n}=22 ; A$. albosignatus and $A$. callipygius with $2 \mathrm{n}=20$; and $A$. leucopygius with $2 \mathrm{n}=18$ (A. albosignatus group).

It is important to emphasise that several individuals of these species have been collected in more than one locality and no karyotype intraspecific variation in the chromosome number has been found except, at the first sight, in the sample of $A$. albofrenatus ( $2 \mathrm{n}=24$ in Floresta da Tijuca, Rio de Janeiro, RJ, and $2 \mathrm{n}=22$ in Boraceia, SP) and $A$. albosignatus $(2 \mathrm{n}=20$ in Boraceia, SP, and $2 \mathrm{n}=18$ in Teresópolis, RJ) [8], although this variation was probably consequence of misidentification, according to the author. Later, Carvalho et al. $[9,10]$, based on the geographical distribution of Aplastodiscus and on the cytogenetic data of some individuals collected in the same or near the localities screened by Bogart [8], concluded that the formerly karyotyped specimens were actually misidentification, and suggested that the animals with $2 \mathrm{n}=22,2 \mathrm{n}=20$, and $2 \mathrm{n}=18$ corresponded to A. arildae, A. albosignatus, and A. leucopygius, respectively. Additionally, considering that the range of $A$. perviridis includes the state of Rio de Janeiro [7] and that the diploid number for this species is 


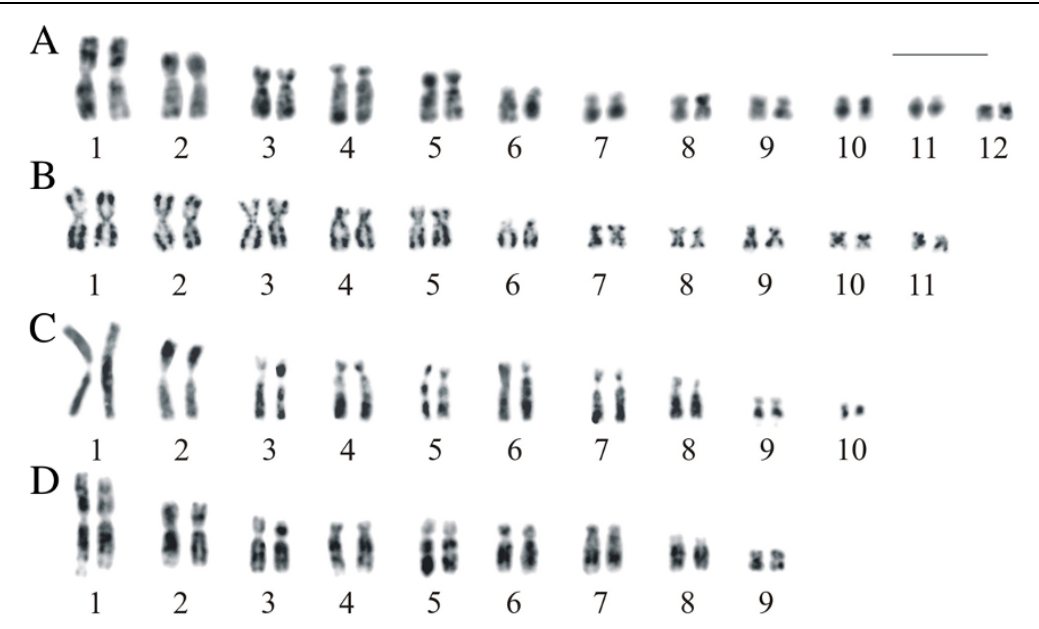

Figure 6 Replication-banded karyotypes of Aplastodiscus, after BrdU incorporation. A. A. perviridis; B. A. arildae; C. A. callipygius; D. A. leucopygius. Bar $=10 \mu \mathrm{m}$

$2 \mathrm{n}=24$ [10, present work], the A. albofrenatus from Tijuca Forest, RJ [8], could be $A$. perviridis or some other species of Aplastodiscus.

Observing the karyotypes analysed so far with standard Giemsa staining, it was noticed that, although the ordering or the nomenclature adopted for each chromosome pair could differed among the authors, the chromosome constitution was equivalent within each group of species. Even presenting distinct diploid numbers, some shared characteristics could be recognized: the first five chromosome pairs in A. perviridis, A. callipygius, and A. leucopygius were equivalent in morphology and relative size; similarity also exists for the first five pairs of $A$. arildae and $A$. eugenioi, both exhibiting $2 \mathrm{n}=22$ karyotypes, but their pair 2 is clearly metacentric and larger than the 2 observed in the three former species; all six species exhibited a subtelocentric medium-sized marker but in distinct positions in the karyograms, that is, in the majority of the species the marker was the pair 6, whereas in A. callipygius and A. leucopygius it corresponded to pair 8. On the other hand, some conspicuous karyotype differences could be pointed out: a progressive reduction in the number of the small pairs, totalling six in A. perviridis, five in A. arildae and A. eugenioi, two in A. callipygius, and one in $A$. leucopygius; the presence in A. callipygius and A. leucopygius of two large-sized chromosome pairs 6 and 7, not observed in any other karyotype.

Taking into account that $2 \mathrm{n}=24$ was considered a synapomorphy for Hylinae [5], most probably the ancestor of Aplastodiscus had 24 chromosomes (Figure 7A), and the karyotype constitution would be equivalent to that observed in the related genera Bokermannohyla and Hypsiboas, as well as to that of the $2 \mathrm{n}=24$ A. cochranae and A. perviridis. Therefore, the chromosome evolution within the genus Aplastodiscus occurred primarily by reducing the diploid number from an ancestor with $2 \mathrm{n}=24$ due to chromosome fusions. However, replication banding data obtained for the first time in species of Aplastodiscus could not be used for identifying the probable structural rearrangements, although correspondence of banding patterns had been confirmed among some chromosomes.

Other analysis provided additional data on the karyotype variability within the genus Aplastodiscus. Both Agimpregnation and FISH with an rDNA probe confirmed one pair of NOR-bearing chromosomes for all species. The eventual heteromorphism of Ag-NOR, that is, presence and lack of labelling in metaphases of some of the individuals in all analysed species, was interpreted as result rather from a differential activity than from the deletion in the amount of rDNA repeats, since two FISH signals, equivalent in size in both homologues, were observed in all cases. So, the transcriptional activity of rDNA might be inactivated or to be too low to be detected by silver impregnation in some chromosomes.

In $A$. perviridis, $A$. arildae, A. callipygius, and A. leucopygius, the NOR was located in a homeologous smallsized chromosome, although corresponding to the 11 in the two former species and to 9 in the two latter, due to the reduction in the diploid number. This condition of NOR in one of the smallest chromosome pairs was also observed in other species of Aplastodiscus [9,10], as well as in the hylids of genera Bokermannohyla, Hyla, Hypsiboas, and those belonging to Scinax of rubber clade [25-32], and this can be considered a plesiomorphy for the family. These marker chromosome pairs are most probably homeologous, although with non-coincident position in the case of the karyograms of species with the same chromosome number.

In A. eugenioi of the present sample and from the literature [9], the NOR had a derived location, in a medium-pair 6, or pair 7 in the case of $A$. ehrhardti and $A$. albofrenatus, but the latter species had an additional 


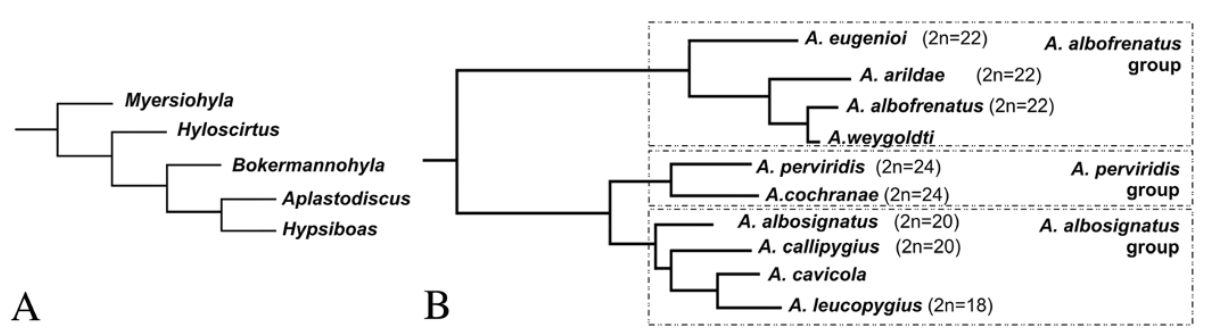

Figure 7 Adapted phylogenies. A. phylogenetic tree of Tribe Cophomantini (Hylinae, Hylidae) based on Faivovich et al. [5], showing the position of Aplastodiscus and related genera Hypsiboas and Bokermannohyla; B. phylogenetic tree of genus Aplastodiscus based on Wiens et al. [6], with indication of the known diploid number of each karyotyped species [9, 10, present work].

NOR site in chromosome 1 [9]. In the three species the medium-sized pairs bearing NOR, referred by us as the 6 , were probably the same, and this condition may constitute a synapomorphy. Gross structural rearrangement seemed not to be the mechanism underlying the change of NOR from a small-sized to a medium-sized chromosome, because the chromosome 6 was always recognized as a subtelocentric marker in all species, independently if bearing or not NOR. Minute structural rearrangements, transposition by means of mobile elements or other mechanisms were not discarded, but they were not demonstrated through the used banding techniques. These mechanisms would also explain the change of NOR from the long to the short arms of chromosome 9 in A. leucopygius.

All the sampled species of Aplastodiscus had similar heterochromatin distribution, with $\mathrm{C}$-bands in the centromeres and at the NOR sites. Our data on A. perviridis, A. arildae, and A. eugenioi differed from the Cbanding pattern of the corresponding species previously analysed $[9,10]$, that demonstrated additional secondary $\mathrm{C}$-positive regions in some chromosome pairs. This might be indicative of population difference or even be result of technical procedures. In spite of the apparent uniformity in the C-banding, an unequivocal molecular heterogeneity of the heterochromatin was revealed by $\mathrm{CMA}_{3}$ staining and FISH with a telomeric probe. In fact, the centromeric heterochromatin of the chromosomes of $A$. perviridis was GC-rich repetitive region, as shown by its bright fluorescence after $\mathrm{CMA}_{3}$ staining. On the other hand, the hybridisation of the telomeric probe outside of the ends of all chromosomes in $A$. arildae and $A$. eugenioi, and chromosome 3 in A. leucopygius, indicated the presence of repeats similar to (TTAGGG) $)_{\mathrm{n}}$ in the centromeric region. Another possible type of centromere repetitive region corresponded to that of the chromosomes of A. callipygius and A. leucopygius, since neither the base-specific fluorochromes nor the telomeric probe yielded a fluorescent labelling.

Occasionally, interstitial hybridisation of the telomeric probe may represent true vestiges of telomeres, corroborating structural rearrangements occurred during chromosome evolution, as described in rodents $[33,34]$. Nevertheless, this possibility was excluded in the Aplastodiscus species [9, present work], and in other frogs presenting ITS $[35,36]$. Regardless, the presence of repetitive DNA bearing telomere-like sequences outside the telomeres might represent an additional cytological marker for species or even species groups.

The meiotic analysis in $A$. arildae, $A$. callipygius, and $A$. leucopygius confirmed the occurrence of multivalent chromosome pairing, as described in A. albofrenatus and A. arildae [9]. While in our sample of $A$. arildae and A. callipygius a clear tetravalent pairing was seen, in A. leucopygius the tetravalent figure was not characteristic, because the involved chromosomes formed two recognizable bivalents. In all these three species, the chromosomes of the largest pair were involved in the tetravalent.

In vertebrates, including frogs [37-40], rings or chains of meiotic multivalents have been reported. The most illustrative case among animals was described in Ornithorhynchus anatinus [41], in which the multivalent formation was attributed to sequential reciprocal translocations. The same occurred in one specimen of the frogs Haddadus binotatus [39] and Leptodactylus pentadactylus [40], which presented meiotic chain and several odd heteromorphic chromosomes in their karyotypes.

In our study there was no evidence of reciprocal translocation to explain the tetravalent formation, unless it involved minute segments, not detected by the used banding techniques. Another explanation would be the non-chiasmatic ectopic pairing between terminal repetitive sequences of non-homologous chromosomes, proposed by Schmid et al. [12] as a reasonable alternative for similar cases described in the literature $[9,37,38]$. Our data gave no support to any of these hypothesis.

Our cytogenetic analysis on Aplastodiscus and the comprehensive comparative analysis allowed us to consider the following possible homeologies: chromosomes 1,4 , and 5 of $A$. perviridis, A. arildae, A. callipygius, and A. leucopygius; the chromosome 2 of A perviridis, A. callipygius, and $A$. leucopygius with the chromosome 3 
of $A$. arildae and $A$. eugenioi; the chromosomes 3 of $A$. perviridis, $A$. callipygius, and $A$. leucopygius; the chromosomes 6 and 11 of $A$. perviridis, $A$. arildae, and $A$. eugenioi with the chromosomes 8 and 9, respectively, of A. callipygius and A. leucopygius; the chromosomes 7, 8, 9, and 10 of $A$. perviridis, $A$. arildae, and A. eugenioi; and the chromosome 12 of $A$. perviridis with the chromosome 10 of $A$. callipygius. The corresponding chromosome 2 of $A$. arildae and $A$. eugenioi, and the chromosomes 6 and 7 of A. callipygius and A. leucopygius were interpreted as resulted of rearrangement. Based on these presumed data, the chromosome evolution in the genus Aplastodiscus from an ancestor with $2 n=24$ was outlined. Nevertheless, two evolutionary pathways were proposed: one involving two fusions events, in which participate the small elements $7,8,9$, and 10, giving rise to two new large-sized pairs 6 and 7, as in the karyotype with $2 \mathrm{n}=20$ of $A$. callipygius and with $2 \mathrm{n}=18$ of $A$. leucopygius; and the other, fusion involving the small chromosome 12 and the large chromosome 3 , giving rise to the metacentric pair 2 , as in the karyotypes with $2 \mathrm{n}=22$ of $A$. arildae and $A$. eugenioi. This hypothesis is supported by our present cytogenetic data, but undoubtedly, other resolute approaches (e.g., chromosome painting, gene linkage, among others) are still necessary in order to confirm the chromosome evolution within the genus Aplastodiscus.

Another achievement of the present study was the confirmation, by means of chromosome analysis, of the relationships among species or species groups of Aplastodiscus, as shown in the adapted phylogenetic tree based in Wiens et al. [6], and shown in Figure 7B. Including the known diploid numbers of all karyotyped species, the two pathways in the chromosome evolution were well visualised, and the cytogenetic data gave support to the molecular phylogeny and distribution of the species in the known groupings. Certainly, further species sampling, especially of those that have never been karyotyped, will be of great interest to confirm or not the relationships within the genus Aplastodiscus.

\begin{abstract}
Abbreviations
2n: diploid number; Ag-NOR: nucleolar organiser region marked by silver impregnation; BrdU: 5-bromodeoxiuridine; $\mathrm{CMA}_{3}$ : Chromomycin A3; DAPI: 416-diamidino-2-phenylindole; FISH: Fluorescent in situ hybridization; FPG: Fluorochrome Plus Giemsa; FN: Fundamental number; ITS: Interstitial telomeric sequence; NOR: Nucleolar organiser region; rDNA: Ribosomal DNA.
\end{abstract}

\section{Competing interests}

Non-financial competing interests.

\section{Authors' contributions}

SLG performed the cytogenetic studies and drafted the manuscript. JZ collected some animals and helped in the review of the manuscript. HN collected some animals and helped with identification. CFBH provided support on zoological information, carried out the species identification, and revised the manuscript. SK supervised the cytogenetic studies, participated in the draft, and in the revision of the final text. All authors read and approved the final manuscript.

\section{Acknowledgments}

The authors are grateful to Fundação de Amparo à Pesquisa do Estado de São Paulo (FAPESP) and Conselho Nacional de Desenvolvimento Científico e Tecnológico (CNPq) for financial support. They also thank to Instituto Brasileiro do Meio Ambiente e dos Recursos Naturais Renováveis (IBAMA) for providing the collection license to $\mathrm{JZ}, \mathrm{HN}$, and $\mathrm{CFBH}$.

\section{Author details}

'UNESP, Universidade Estadual Paulista, Instituto de Biociências, Departamento de Biologia, Av. 24A, 1515, 13506-900, Rio Claro, SP, Brazil. ${ }^{2}$ Universidade Estadual do Sudoeste da Bahia, Departamento de Ciências Biológicas, Rua José Moreira Sobrinho, s/n, 45206-000, Jequié, BA, Brazil. ${ }^{3}$ UNESP, Universidade Estadual Paulista, Instituto de Biociências, Departamento de Zoologia, Av. 24A, 1515, 13506-900, Rio Claro, SP, Brazil.

Received: 10 January 2012 Accepted: 15 April 2012

Published: 20 April 2012

\section{References}

1. Garcia PCA, Caramaschi U, Kwet A: O status taxonômico de Hyla cochranae Mertens e a recaracterização de Aplastodiscus A. Lutz (Anura, Hylidae). Revista Brasileira de Zoologia 2001, 18:1197-1218.

2. Caramaschi U: Aplastodiscus A. Lutz, 1950, um sinônimo júnior de Hyla Laurenti, 1768 (Amphibia, Anura, Hylidae) [abstract]. Congresso Brasileiro de Zoologia 1983, 10:307

3. Cruz CAG, Peixoto AL: Espécies verdes de Hyla: o complexo "albofrenata" (Amphibia, Anura, Hylidae). Arquivos da Universidade Federal Rural do Rio de Janeiro 1985, 8:59-70.

4. Haddad CFB, Faivovich J, Garcia PCA: The specialized reproductive mode of the treefrog Aplastodiscus perviridis (Anura: Hylidae). Amphib-reptil 2005, 26:87-92.

5. Faivovich J, Haddad CFB, Garcia PCA, Frost DR, Campbell JA, Wheeler WC: Systematic review of the frog family Hylidae, with special reference to Hylinae: phylogenetic analysis and taxonomic revision. Bull Am Mus Nat His 2005, 294:1-240.

6. Wiens JJ, Kuczynski CA, Hua X, Moen D: An expanded phylogeny of treefrogs (Hylidae) based on nuclear and mitochondrial sequence data. Mol Phylogenet Evol 2010, 55:871-882.

7. Frost DR: Amphibians of the world: an on-line reference. V5.5. [http:// research.amnh.org/herpetology/amphibia/index.html]

8. Bogart JP: Evolution of anuran karyotypes. In Evolutionary Biology of Anurans. Edited by Vial JL. Columbia: University of Missouri Press; 1973:337-349.

9. Carvalho KA, Garcia PCA, Recco-Pimentel SM: NOR dispersion, telomeric sequence detection in centromeric regions and meiotic multivalent configurations in species of the Aplastodiscus albofrenatus group (Anura, Hylidae). Cytogenet Genome Res 2009, 126:359-367.

10. Carvalho KA, Garcia PCA, Recco-Pimentel SM: Cytogenetic comparison of tree frogs of the genus Aplastodiscus and the Hypsiboas faber group (Anura, Hylidae). Genet Mol Res 2009, 8:1498-1508.

11. Schmid M, Steinlein C, Nanda I, Epplen JT: Chromosome banding in Amphibia. In Cytogenetics of Amphibians and Reptiles. Edited by Olmo E. Basel: Birkhauser Verlag; 1990:21-45.

12. Schmid M, Steinlein C, Bogart JP, Feichtinger W, León P, La Marca E, Diaz LM, Sans A, Chen S-H, Hedges SB: The chromosomes of Terraranan frogs: insights into vertebrate cytogenetics. Cytogenet Genome Res 2010, 130131:1-568.

13. Baldissera FA Jr, Oliveira PSL, Kasahara S: Cytogenetics of four Brazilian Hyla species (Amphibia-Anura) and description of a case with a supernumerary chromosome. Rev Bras Genet 1993, 16:335-345.

14. Schmid M: Chromosome banding in Amphibia I. Constitutive heterochromatin and nucleolus organizers regions in Bufo and Hyla. Chromosoma 1978, 66:361-388.

15. Silva APZ, Haddad CFB, Kasahara S: Chromosomal studies on five species of the genus Leptodactylus Fitzinger, 1826 (Amphibia, Anura) using differential staining. Cytobios 2000, 103:25-38. 
16. Howell WM, Black DA: Controlled silver-staining of nucleolus organizer regions with a protective colloidal developer: 1-step method. Experientia 1980, 36:1014-1015.

17. Sumner AT: A simple technique for demonstrating centromeric heterochromatin. Exp Cell Res 1972, 75:304-306.

18. Christian A, McNiel E, Robinson J, Drabek J, LaRue C, Wadren C, Bedford JA: A versatile image analysis approach for simultaneous chromosome identification and localization of FISH probes. Cytogenet Cell Genet 1998, 82:172-179.

19. Dutrillaux B, Couturier J: La Pratique de l'Analyse Chromosomique. Paris: Masson; 1981

20. Matsuda Y, Chapman VM: Application of fluorescence in situ hybridization in genome analysis of the mouse. Electrophoresis 1995, 16:261-272.

21. Meunier-Rotival M, Cortadas J, Macaya G: Isolation and organization of calf ribosomal DNA. Nucleic Acids Res 1979, 6:2109-2123.

22. Pinkel D, Straume T, Gray JW: Cytogenetic analysis using quantitative, high-sensitivity, fluorescence hybridization. Proc Natl Acad Sci U S A 1986, 83:2934-2938.

23. Green DM, Sessions SK: Nomenclature for chromosomes. In Amphibian Cytogenetics and Evolution. Edited by Green DM, Sessions SK. San Diego: Academic Press; 1991:431-432

24. Green DM, Sessions SK: Karyology and Cytogenetics. In Amphibian Biology. Volume 7. Edited by Heatwole H, Tyler M. Chipping Norton: Surrey Beatty and Sons; 2007:2756-2841.

25. Catroli GF, Kasahara S: Cytogenetic data on species of the family Hylidae (Amphibia, Anura): results and perspectives. Publicatio: Ciências Biológicas e da Saúde 2009, 15:67-86.

26. Wiley JE: Chromosome banding patterns of treefrogs (Hylidae) of the Eastern United States. Herpetologica 1982, 38:507-520.

27. King M, Contreras $\mathrm{N}$, Honeycutt RL: Variation within and between nucleolar organizer regions in Australian hylid frogs (Anura) shown by 18 S + 28 S in-situ hybridization. Genetica 1990, 80:17-29.

28. Anderson K: Chromosome evolution in Holarctic Hyla treefrogs. In Amphibian Cytogenetics and Evolution. Edited by Green DM, Sessions SK. San Diego: Academic Press; 1991:299-331.

29. Kasahara S, Silva APZ, Gruber SL, Haddad CFB: Comparative cytogenetic analysis on four tree frog species (Anura, Hylidae, Hylinae) from Brazil. Cytogenet Genome Res 2003, 103:155-162.

30. Gruber SL, Haddad CFB, Kasahara S: Chromosome banding in three species of Hypsiboas (Hylidae, Hylinae), with special reference to a new case of $\mathrm{B}$-chromosome in anuran frogs and to the reduction of the diploid number of $2 n=24$ to $2 n=22$ in the genus. Genetica 2007, 130:281-291.

31. Cardozo DE, Leme DM, Bortoleto JF, Catroli GF, Baldo D, Faivovich J, Kolenc F, Silva APZ, Borteiro C, Haddad CFB, Kasahara S: Karyotypic data on 28 species of Scinax (Amphibia: Anura: Hylidae): diversity and informative variation. Copeia 2011, 2:251-263.

32. Catroli GF, Faivovich J, Haddad CFB, Kasahara S: Conserved karyotypes in Cophomantini: cytogenetic analysis of 12 species from 3 species groups of Bokermannohyla (Amphibia: Anura: Hylidae). J Herpetol 2011, 45:120-128.

33. Fagundes $V$, Yonenaga-Yassuda Y: Evolutionary conservation of whole homeologous chromosome arms in the Akodont rodents Bolomys and Akodon (Muridae, Sigmodontinae): maintenance of interstitial telomeric segments (ITBs) in recent event of centric fusion. Chrom Res 1998, 6:643-648.

34. Ventura K, O'Brien PCM, Yonenaga-Yassuda Y, Ferguson-Smith MA: Chromosome homologies of the highly rearranged karyotypes of four Akodon species (Rodentia, Cricetidae) resolved by reciprocal chromosome painting: the evolution of the lowest diploid number in rodents. Chrom Res 2009, 17:1063-1078.

35. Meyne J, Baker AJ, Hobart HH, Hsu TC, Ryder OA, Ward OG, Wiley JE, Wurster-Hill DH, Yates TL, Moyziz RK: Distribution of non-telomeric sites of the (TTAGGG) telomeric sequence in vertebrate chromosomes. Chromosoma 1990, 99:3-10.

36. Wiley JE, Meyne J, Little ML, Stout JC: Intersticial hybridization sites of the (TTAGGG) $n$ telomeric sequence on the chromosomes of some North American hylid frogs. Cytogenet Cell Genet 1992, 61:55-57.

37. Lourenço LB, Recco-Pimentel SM, Cardoso AJ: Polymorphism of the nucleolus organizer regions (NORs) in Physalaemus petersi (Amphibia, Anura, Leptodactylidae) detected by silver staining and fluorescence in situ hybridization. Chrom Res 1998, 6:621-628.
38. Siqueira S Jr, Ananias F, Recco-Pimentel SM: Cytogenetics of three Brazilian species of Eleutherodactylus (Anura, Leptodactylidae) with 22 chromosomes and re-analysis of multiple translocations in E. binotatus. Genet Mol Biol 2004, 27:363-372.

39. Campos JRC, Ananias F, Haddad CFB, Kasahara S: Karyotypic similarity among Barycholos ternetzi and five species of the genus Eleutherodactylus from southeastern Brazil (Anura, Brachycephalidae). Micron 2006, 39:151-159.

40. Gazoni T, Gruber SL, Silva APZ, Araújo OGS, Strüssmann C, Haddad CFB, Kasahara S: Comparative cytogenetic analyses of Leptodactylus (Amphibia, Anura, Leptodactylidae), with description of a new karyotype and a case of multiple sequential translocations [abstract]. Reunião Brasileira de Citogenética 2011, 2:22.

41. Grützner F, Rens W, Tsend-Ayush E, El-Mogharbell N, O'Brien PCM, Jones RC, Ferguson-Smith MA, Graves JAM: In the platypus a meiotic chain of ten sex chromosomes shares genes with the bird $Z$ and mammal $X$ chromosomes. Nature 2004, 3021:1-5.

doi:10.1186/1471-2156-13-28

Cite this article as: Gruber et al.: Comparative karyotype analysis and chromosome evolution in the genus Aplastodiscus (Cophomantini, Hylinae, Hylidae). BMC Genetics 2012 13:28.

\section{Submit your next manuscript to BioMed Central and take full advantage of:}

- Convenient online submission

- Thorough peer review

- No space constraints or color figure charges

- Immediate publication on acceptance

- Inclusion in PubMed, CAS, Scopus and Google Scholar

- Research which is freely available for redistribution
C Biomed Central 